\title{
Are the interaction effects of warming and drought on nutritional status and biomass production in a tropical forage legume greater than their individual effects?
}

\section{Dilier Olivera Viciedo ( $\sim$ dilierolvi@gmail.com )}

Laboratory of Plant Nutrition, Soils and Fertilizers Sector, Department of Agricultural Production Sciences, São Paulo State University “Júlio de Mesquita Filho” (UNESP), Jaboticabal, São Paulo, Brazil https://orcid.org/0000-0002-7975-9508

\section{Renato de Mello Prado}

Laboratory of Plant Nutrition, Soils and Fertilizers Sector, Department of Agricultural Production Sciences, São Paulo State University “Júlio de Mesquita Filho" (UNESP), Jaboticabal, São Paulo, Brazil https://orcid.org/0000-0003-1998-6343

\section{Carlos Alberto Martinez}

Department of Biology, FFCLRP, University of Sao Paulo, Ribeirão Preto, São Paulo, Brazil https://orcid.org/0000-0002-0246-9481

\section{Eduardo Habermann}

Department of Biology, FFCLRP, University of Sao Paulo, Ribeirão Preto, São Paulo, Brazil https://orcid.org/0000-0003-3371-7684

\section{Marisa de Cássia Piccolo}

Laboratory of Nutrient Cycling, Center of Nuclear Energy in Agriculture (CENA), University of São Paulo (USP), Piracicaba, São Paulo, Brazil https://orcid.org/0000-0003-2163-5630

\section{Alexander Calero Hurtado}

Laboratory of Plant Nutrition, Soils and Fertilizers Sector, Department of Agricultural Production Sciences, São Paulo State University “Júlio de Mesquita Filho” (UNESP), Jaboticabal, São Paulo, Brazil https://orcid.org/0000-0001-6536-2908

\section{Rafael Ferreira Barreto}

Laboratory of Plant Nutrition, Soils and Fertilizers Sector, Department of Agricultural Production Sciences, São Paulo State University “Júlio de Mesquita Filho” (UNESP), Jaboticabal, São Paulo, Brazil https://orcid.org/0000-0002-1170-5386

\section{Kolima Peña Calzada}

Laboratory of Plant Nutrition, Soils and Fertilizers Sector, Department of Agricultural Production Sciences, São Paulo State University “Júlio de Mesquita Filho" (UNESP), Jaboticabal, São Paulo, Brazil https://orcid.org/0000-0003-4883-4293 


\section{Research Article}

Keywords: Plant-climate interactions, drought, warming, tropical ecosystems, Stylosanthes capitata Posted Date: June 29th, 2021

DOl: https://doi.org/10.21203/rs.3.rs-664841/v1

License: (c) (i) This work is licensed under a Creative Commons Attribution 4.0 International License. Read Full License 


\section{Abstract}

Climate change effects on natural and managed ecosystems are difficult to predict due to its multi-factor nature. However, most studies which investigate the impacts of climate change factors on plants, such as warming or drought, were conducted under one single stress and controlled environments. In this study, we evaluated the effects of elevated temperature $\left(+2^{\circ} \mathrm{C}\right)(\mathrm{T})$ under different conditions of soil water availability $(\mathrm{W})$ to understand the interactive effects of both factors on leaf, stem, and inflorescence macro and micronutrients concentration and biomass allocation of a tropical forage species, Stylosanthes capitata Vogel under field conditions. Temperature control was performed by a Temperature Free-Air Controlled Enhancement (T-FACE) system. We observed that warming changed nutrient concentrations and plant growth depending on soil moisture levels, but the responses were specific for each plant-organ. In general, we observed that warming under well-watered conditions greatly improved nutrient concentration and biomass production, whilst the opposite effect was observed under nonirrigated and non-warmed conditions. However, under warmed and non-irrigated conditions, we observed that leaf biomass and leaf nutrient concentration greatly reduced when compared to non-warmed and irrigated plants. Our findings suggest that warming $\left(2^{\circ} \mathrm{C}\right.$ above ambient temperature) and drought, as well as both combined stresses, will change the nutrient requirements and biomass distributions between plant aerial organs of $S$. capitata in tropical ecosystems, which may impact animal feeding in the future.

\section{Introduction}

During centuries, humans have been changing the atmospheric chemistry by adding gigatons of greenhouse gases on the atmosphere, resulting in an additional radiative forcing on climate responsible for warming the troposphere during the last decades. Recent studies indicated that warming will likely exceed $2^{\circ} \mathrm{C}$ by 2100 , while more extreme average temperature increases such as surpassing $4.5^{\circ} \mathrm{C}$ is unlikely to happen (Sherwood et al., 2020). A warmer atmosphere brings many other consequences to regional and global climate patterns such as changes in rainfall distribution and intensity (Tietjen et al., 2017). Moreover, climate change involves simultaneous modifications in complexes set of climate variables that interact to each other (e.g., temperature, water availability, atmospheric $\mathrm{CO}_{2}$ levels), potentially affecting crop productivity and causing yield losses (Habermann et al., 2020; Olivera-Viciedo et al., 2019, 2021a; Ortiz-Bobea et al., 2021). Therefore, countries that are highly dependent on agriculture as the major economic activity are the most vulnerable to climate change, creating an urgent need for studies to understand how these regions will be impacted by climatic changes.

Plant growth and development depend upon environmental variables, such as temperature, light intensity, nutrients, and water availability (Hermans et al., 2006; Liu et al., 2020). However, under field conditions, crops are exposed to different abiotic stresses simultaneously. Abiotic stress induced by climate change is considered to be a leading threat to the worldwide agricultural productivity (Khanzada et al., 2020). Under abiotic stress, plants adjust its physiology, nutrient uptake, and biomass production and allocation, investing in organs that are involved in acquiring scarce resources (Marschner, 2011; Olivera-Viciedo et al., 2021a). 
It's widely known that plants responses and vulnerabilities to concomitant abiotic stresses cannot be directly extrapolated from studies that evaluate each stress individually, since interactive effects are at play under field conditions (Barreto et al., 2020; Habermann et al., 2021; Olivera-Viciedo et al., 2019, 2021b). This presupposes that the response of plants in adverse situations is dependent (at least in part) on their adaptation and tolerance to combined stress conditions. Therefore, multifactorial experiments are crucial when evaluating plant responses to climate change variables.

The impacts of warming, drought and their combination on tropical ecosystems are of great concern, since these regions plays important roles in global carbon sink (Olivera-Viciedo et al., 2019, 2021a, 2021b). Water restriction combined with a warmer atmosphere are primary abiotic environmental factors that limit crop production (Wang et al., 2020). Both stresses detrimentally decrease dry biomass, forage quality and stoichiometric homeostasis, although the effects depend on plant species or photosynthetic pathway $\left(\mathrm{C}_{3}\right.$ or $\mathrm{C}_{4}$ ) (Habermann et al., 2021; Olivera-Viciedo et al., 2021b). Often, warming conditions simultaneously occurs with drought stress and aggravates their individual influences on physical damages, physiological, biochemical, and nutritional disruptions (Habermann et al., 2019a, 2019b; Ventura et al., 2020). However, warming under well-watered conditions may improve plant growth and nutrient acquisition, due to higher transpiration flux and nutrient demand (Olivera-Viciedo et al., 2021b).

The Food and Agriculture Organization of the United Nations (FAO), reports that permanent meadows and pastures covers approximately 3.4 billion hectares (Mha), which represents approximately $69 \%$ of the world's agricultural area (O'Mara, 2012). In Brazil, almost $90 \%$ of beef cattle are produced on unfertilized pasture and under rainfed conditions (Habermann et al., 2021). Brazilian livestock plays a significant role in country economy, accounting for approximately $31 \%$ of the Gross Domestic Product (GDP) of agribusiness (Veloso et al., 2020). It should also be noted that Brazil is the second largest exporter of beef in the world, with the second largest commercial herd, which is estimated in about 214.7 million cattle heads, mostly grass-fed (IBGE, 2020). Therefore, these ecosystems are an important resource for the country, since it can be used as food for it is cattle, and also present a great potential for mitigation of greenhouse gas emissions (Bustamante et al., 2012; Herrero et al., 2016; Ikhuoso et al., 2020). Despite tropical forage legumes were first used on a wide scale several decades ago in the northeasterly Australian Shaw, (1961), currently, most tropical pasture, mainly in Brazil, are dominated by C4 grasses like Brachiaria brizantha, Megathyrsus maximus, and to a lesser extent by C3 legumes like Stylosanthes capitata Vogel (Boddey et al., 2020; Olivera-Viciedo et al., 2021a, 2021b).

In this study, we used a temperature-free air-controlled enhancement (T-FACE) system to assess how warming combined with different levels of soil water availability should impact nutrient concentration and biomass distribution between different plant aerial-organs of $S$. capitata under field experimental condition. S. capitata Vogel (Fabaceae, Papilionoideae, Dalbergieae) is considered one of the most economically important tropical forage legumes with a wide distribution in Brazil, where 25 out of the 40 species of this genus are reported (Santos et al., 2009). 
Therefore, the aim of this study is to evaluate warming effects under different conditions of soil water availability on nutrients concentration and biomass production of different plant aerial-organs of $S$. capitata under field experimental conditions. Here, we conducted an experiment under field condition using a T-FACE system to test two main hypotheses: 1) Warming effects will depend on soil water availability, and 2) the effects of experimental treatments will be different for each organ.

\section{Material And Methods}

\subsection{Installation and conduction of the experiment}

Here we present evidence of a $\sim 5$ months warming event $\left(2^{\circ} \mathrm{C}\right.$ above ambient temperature) under different conditions of soil water availability on a tropical pasture located in Brazil under field conditions using a T-FACE system. The study was carried out in an area of $2500 \mathrm{~m}^{2}$ located at Ribeirão Preto campus of the University of São Paulo (USP), SP, Brazil ( $21^{\circ} 10^{\prime} 8$ "S, $47^{\circ} 51^{\prime} 48^{\prime \prime W}$ ) (further details, see Olivera-Viciedo et al. 2021a, and supplementary data cited therein). The soil in this area is classified as a Rhodic Ferralsol with a clay texture, where the annual average temperature is $22^{\circ} \mathrm{C}$, and average yearly precipitation of $1508 \mathrm{~mm}$ (Climate-Data, 2020). The design, operation of the T-FACE system, and the soil water deficit induction are described in details in Olivera-Viciedo et al. (2021a).

\subsection{Experimental design and plant growth}

Treatments were arranged in a randomized block design with three replications in a $2 \times 2$ factorial scheme with two factors with two levels each: canopy temperature $(\mathrm{T})$ : elevated (eT) and ambient (aT), and soil water regime (W): irrigated (IR) and non-irrigated (NIR), distributed in 12 plots of $16 \mathrm{~m}^{2}(4 \times 4 \mathrm{~m})$, where we created four combinations: (i) irrigated and ambient temperature (IRaT), (ii) irrigated and $+2^{\circ} \mathrm{C}$ above ambient temperature (IReT), (iii) non-irrigated and ambient temperature (NIRaT), (iv) non-irrigated and $+2^{\circ} \mathrm{C}$ above ambient temperature (NIReT). Seeds of S. capitata cv "Campo Grande" were sown on November 2017 (early summer) and after seeding and pasture establishment ( 4 months), half of the plots were submitted to a rainfed period (i.e., drip irrigation was suspended) for 21 days, and the other half were irrigated as necessary to maintain the soil water content (SWC) at $\sim 0.50 \mathrm{~m}^{3}$ water $\mathrm{m}^{-3}$ soil. During the rainfed period, no precipitation was observed. Warming treatment was applied since sowing and therefore, seedling growth and pasture establishment of warmed plots occurred under $a+2^{\circ} \mathrm{C}$ warming, totalizing $\sim 5$ months of warming treatment.

\subsection{Aboveground biomass and nutrients analysis}

Every week after the beginning of the rainfed period, aboveground biomass production was estimated using the square method, with an area of $0.2 \mathrm{~m} \times 0.2 \mathrm{~m}\left(0.04 \mathrm{~m}^{2}\right)$. Three areas were randomly sampled per plot and mixed to form a composite sample. All collected plants were separated into leaves, inflorescences, and stems. Immediately, all plants were washed with neutral detergent solution $(0.2 \%)$, $\mathrm{HCl}$ solution $(0.1 \%)$, and finally deionized water (Olivera-Viciedo et al., 2020). Then, plant material was dried in a forced air circulation oven $\left(65 \pm 5^{\circ} \mathrm{C}\right)$ until a constant weight to calculate total dry biomass for 
each tissue. Later, it was pulverized an electric mill (Willey type), and the powder samples were used for the chemical analyses of macronutrient $(\mathrm{K}, \mathrm{Ca}$, and $\mathrm{Mg})$ and micronutrients $(\mathrm{Cu}, \mathrm{Fe}, \mathrm{Mn}$, and $\mathrm{Zn})$. From the digestion of the samples in nitric acid $\left(\mathrm{HNO}_{3}\right)$ and perchloric acid $\left(\mathrm{HClO}_{4}\right)$ solution, $\mathrm{K}, \mathrm{Ca}, \mathrm{Mg}$, and micronutrients content were determined by atomic absorption spectrophotometry (Bataglia et al., 1983). For the nutrients analysis, we established the last sampling ( 21 days after the beginning of the rainfed period) as effective sampling during a single growth period to reflect the local agricultural practice (Olivera-Viciedo et al., 2019).

\subsection{Statistical analysis}

We used a factorial two-way analysis of variance (ANOVA), having initially assessed the homogeneity of variance to test the main effects of two levels of soil water regime $(W)$ and two canopy temperatures $(T)$, as well as their interactions $(T \times W)$. The data normality was checked by the Shapiro-Wilk test. The mean values were compared using the least significant difference (LSD) Fisher test with a significance level of $p$-value less than 0.05 . When necessary, we performed a student-t test to compare two average values. $A$ multiple correlation analysis was performed between leaf concentration of certain nutrients $(\mathrm{K}, \mathrm{Ca}, \mathrm{Mg}$, $\mathrm{Cu}, \mathrm{Fe}, \mathrm{Mn}$, and $\mathrm{Zn}$ ) to total concentration of the same nutrient versus leaf dry biomass to total biomass to evaluate the allocation, relation or dependency between nutrient and biomass allocation. We used the SAS software (version 9.4) to conduct all the statistical analyses.

\section{Results}

\subsection{Nutrient concentrations in different plant aerial-organs}

Each organ was differentially affected by treatments and there was no consistent pattern of response to warming and rainfed conditions for both, macronutrients and micronutrients (Fig. 1 and Fig. 2, Table S1, $\mathrm{S} 2$, and $\mathrm{S} 3$ ). Stem $\mathrm{K}$ concentration $[\mathrm{K}]$ decreased under all experimental conditions, while inflorescences $[K]$ increased under all experimental conditions (Fig. 1A, Table S1). However, for leaf [K] we observed an interactive effect between temperatures and soil water availability $(T \times W)$ which resulted in higher $[K]$ under warming, although only under well-watered conditions (IReT, $p \leq 0.001$ ), with an increase in $57 \%$ compared to NIReT (Fig. 1A-C).

We observed that an interactive effect $(T \times W)$ decreased in $47.6 \%$ stem Ca concentration [Ca] under NIReT when compared to current conditions (IRaT) (Student-t test comparison) (Fig. 1B, Table S2). Leaf [Ca] increased due to warming effects, resulting in a $69 \%$ higher leaf [Ca] under NIReT when compared to IRaT (Fig. 1B, Table S2). For inflorescences [Ca], we observed antagonistic effects between $T \times W$, resulting in less [Ca] under irrigated plots (IRaT, IReT) when compared to non-irrigated (NIRaT, NIReT), regardless of temperature effect (Fig. 1B, Table S2). For stem Mg concentration [Mg], we observed that warming as an isolated factor decreased [Mg], whilst NIRaT conditions increased stem [Mg], resulting in an interactive effect under NIReT responsible for decreasing stem [Mg] in approximately $35 \%$ when compared to IRaT (Student-t test comparison) (Fig. 1C, Table S3). Leaf [Mg] was not affected by treatments, whilst inflorescences [Mg] decreased under IReT (Fig. 1C, Table S3). 
There was no consistent pattern of response to the isolated effects of warming or rainfed conditions on [Cu], [Fe], [Mn], and [Zn] concentrations in stems, inflorescences, and leaves (Fig. 2, Table S4, S5, S6, S7). However, except for leaf [Cu], we observed a clear tendency of response for leaves under the combined conditions of NIReT and leaf [Fe], [Mn], and [Zn] were reduced under NIReT when compared to current conditions (IRaT) (Student-t test comparison) (Fig. 2, Table S4, S5, S6, S7). Meanwhile, the inflorescences and stems were negatively influenced under NIReT for all micronutrients, except for $\mathrm{Zn}$ in stem, when compared to IRaT (Fig. 2A-D).

\subsection{Correlation analysis between leaf nutrients and biomass}

We conducted a multiple correlation analysis between leaf [nutrient]:aboveground [nutrient] versus leaf biomass:aboveground biomass and we observed significant differences between all experimental treatments (Fig. 3 and Fig. 4). The ratios of leaf $\mathrm{K}, \mathrm{Ca}$, and $\mathrm{Mg}$ vs. biomass ratios (Fig. 3A-C), linearly increased under well-watered soil conditions plus warming (IReT). This positive correlation between leaf $\mathrm{K}, \mathrm{Ca}, \mathrm{Mg}$ concentration, and biomass allocation indicates that the allocation of the two resources is coupled, so that an increase in biomass in the organ results in a corresponding allocation of the element to the same organ. Similar to macronutrients, the micronutrients showed a positive correlation in response to leaf nutrient concentration vs. biomass in IReT treatments (Fig. 4A-D). Higher positive correlation between these parameters could be identified for $\mathrm{Fe}(\mathrm{r}=0.72)$ and $\mathrm{Mn}(0.82)$, respectively, while a weak positive correlation for $\mathrm{Cu}(r=0.25)$ and $\mathrm{Zn}(r=0.13)$.

\subsection{Plant biomass production and distribution}

For plant biomass production, we observed clear patterns of response to temperature and irrigation regime. Rainfed conditions, but not warming, significantly affected aboveground biomass of $S$. capitata (Fig. 5A-C). In the first sampling date (7 days after the beginning of the rainfed period) (Fig. 5A), we observed significant interactions between $\mathrm{W} \times \mathrm{T}$ for leaves, inflorescence, and stems for plant biomass production. Under IReT plots, warming favored an increased biomass allocation for all plant aerial-organs (Fig. 5A-C). For leaves, IReT and IRaT treatments increased dry biomass in $36 \%$ and $25 \%$ compared to $\mathrm{NIReT}$ and IRaT treatments, respectively (Fig. 5A). Within the same soil water regime condition (NIR, plots), there were no significant differences in biomass leaf production regardless of temperature. However, under combined conditions of NIReT, we observed that leaf biomass decreased in approximately $19 \%$ when compared to IRaT (Student-t test comparison).

At the second sampling date (Fig. 5B) We observed that within the same soil water condition (IR plots), warming significant increased dry mass production in all plant aerial-organs, even under non-irrigated conditions for inflorescences (Fig. 5B). Leaf dry biomass was not different between NIReT and IRaT (Student-t test comparison). In the last sampling date (Fig. 5C), dry biomass production increased under irrigated treatments for all plant organs, particularly under elevated temperature (Fig. 5C). However, there was no significant interaction between factors, and only for inflorescences the combinate effect of 
drought plus warming (NIReT, plots) increased compared with individual drought effect (NIRaT). For leaf biomass production, we observed that under NIReT leaf dry mass reduced by approximately $20 \%$ compared to IRaT (Student-t test comparison) (Fig. 5C).

\section{Discussion}

This study investigated the individual and combined effects of two climate change variables (temperature and soil water availability) on nutrient concentration and biomass production of different aerial-organs of a tropical forage legume grown under field conditions. Our data corroborated both initial hypotheses, since warming effects were dependent on soil water availability and warming and irrigation regimes impacted $S$. capitata organs in different ways.

Recent studies on plants acclimation subjected to abiotic stress conditions such as drought or warming, have provided important information over the last years (Habermann et al., 2021; Olivera-Viciedo et al., 2021a). However, plant responses to a single stress cannot be used to infer the effects of combined stresses due to the interactive effects (Olivera-Viciedo et al., 2021b), highlighting the importance of multifactorial studies. Several studies have reported that the responses of plants to warming under different soil water availability are diverse (Hatfield and Prueger, 2015; Kong et al., 2020; Olivera-Viciedo et al., 2019), indicating that more studies that allow a better understanding of the interactions between temperature and soil water content are needed in order develop effective adaptation practices for agronomic systems in response to climate extremes.

Plants respond to environmental changes partitioning biomass to different organs as a mechanism to enhance resource utilization and growth (Olivera-Viciedo et al., 2021b). In this study, biomass production and nutrient concentration of leaves, inflorescence, and stems of $S$. capitata was changed by both environmental factors (Fig. 1 and Fig. 2). Plant responses to different environments can be determined by the nutrient status of its tissues, water status, photosynthetic acclimation, and other factors (Barreto et al., 2020; Habermann et al., 2021; Olivera-Viciedo et al., 2021a; Onoda et al., 2017).

In general, plant nutrient concentrations influence each other during the growing season, especially in the leaf tissues (Olivera-Viciedo et al., 2021b). We observed a significant decrease in [K], [Ca], and [Mg] (Fig. 1A-C), and at the same time, a lower concentration for micronutrients (Fig. 2A-D) in leaves of $S$. capitata, especially under drought plus warming. This result gives support to our first hypothesis, and indicates that warming exacerbated individual effect of reduced soil water availability, affecting even more negatively foliar nutrient concentrations. Furthermore, low soil moisture due to warming can affect the dynamics of soil microbial communities, decomposition and mineralization rates (Oliveira et al., 2020), which may reduce leaf nutrients concentrations (Gerdol et al., 2016), and consequently, a lower plant growth (Fig. 5A-C). It is also known, that warming under reduced soil moisture affect plant stoichiometric homeostasis, leaf/inflorescence and leaf/stem ratios, potentially decreasing aboveground biomass production (Olivera-Viciedo et al., 2021a). We also observed that inflorescences biomass increased by warming effects. This positive effect of warming on flowering of $S$. capitata has been 
recently reported by Alzate-Marin et al. (2021), and has a great potential to change the pollination and reproductive potential of this species under future climate change effect. These results are in agreement with our previous experiment (Olivera-Viciedo et al., 2021a).

S. capitata growth conditions changed the nutrients allocation and biomass between plant aerial-organs. For example, the positive correlation between leaf ratio of macronutrients and micronutrients vs. biomass ratios (Fig. 3, and Fig. 4), as well as biomass allocation for all plant aerial-organs (Fig. 5A-C) under warming and well-watered condition, might be due to a higher leaf nutrient concentration (Fig. 1, Fig. 2), and homeostatic capacity (Olivera-Viciedo et al., 2019), improving the nutrient use efficiency and plant growth in agreement with the results of Olivera-Viciedo et al. (2021b). The underlying mechanisms of this response are probably associated with an improved leaf area, photosynthesis rate and PSIl performance (Martinez et al., 2014). Therefore, our findings clearly suggest that warming, water availability, and nutrients resources strongly control the variations of biomass distributions between different aerialorgans of $S$. capitata grown in the field.

In our previous study, we found that $\mathrm{C}, \mathrm{N}$, and $\mathrm{P}$ stoichiometry of $S$. capitata and their relationships was severely affected by soil water availability, particularly under drought plus warming (Olivera-Viciedo et al., 2021a). In this study, our results implied that drought alone and drought plus warming interaction impact nutrient uptake and biomass allocation, while, warming $\left(+2^{\circ} \mathrm{C}\right.$ above ambient) will be advantageous only under well-watered condition (IR, plots). Warming under well-watered conditions increased leaf $\mathrm{K}, \mathrm{Ca}, \mathrm{Mg}$, $\mathrm{Cu}, \mathrm{Fe}, \mathrm{Mn}$, and $\mathrm{Zn}$ concentration and biomass production for all plant aerial-organs, with a positive correlation between leaf nutrient concentrations vs. biomass ratios. However, there was no consistent pattern for the effects of warming on $\mathrm{K}, \mathrm{Ca}, \mathrm{Mg}, \mathrm{Fe}$, and $\mathrm{Zn}$ concentrations in the stems and $\mathrm{Ca}$, and $\mathrm{Mg}$ in inflorescences.

Mineral composition of forage species is also important for animal nutrition, since nutrients uptake by cattle is almost completely provided by pastures, especially in tropical and subtropical regions (OliveraViciedo et al., 2021b). Here, we observed that a warmer atmosphere under non-irrigated conditions greatly decreased the leaf concentration of many nutrients. This response is especially important, since most of the tropical pastures are rainfed and frequently submitted to water stress periods. In addition, leaves are the main organs that are eaten by animals. Therefore, our results suggests that animal feeding may be impact under future conditions. Previous studies also showed that warming, especially under low soil moisture will reduce forage quality and digestibility of $S$. capitata due to increased concentration of fibers and lignin, and reduced content of leaf crude protein (Habermann et al., 2021). Thus, the results obtained here may amplify the decrease in nutritional value of $S$. capitata found in other studies.

Therefore, we conclude that warming can change leaf nutrient concentrations and plant growth in tropical pasture, but the responses are specific for each plant-organs. Considering there are few field studies in tropical environments that simulate a combination of drought plus warming, our findings bring important insights and inspire further studies in this field.

\section{Compliance with ethics requirements}


This article does not contain any studies with human or animal subjects.

\section{Declarations}

\section{Compliance with ethics requirements}

This article does not contain any studies with human or animal subjects.

\section{Acknowledgments}

The authors thank Wolf Seeds for providing the $S$. capitata seeds. We thank Bruce Kimball from the USDA and Franco Miglietta from IBIMET, Italy. We also thank the postgraduate and undergraduate students who contributed to the field work. Graphical abstract was created with BioRender (biorender.com).

\section{Credit Authorship Contribution Statement}

Dilier Olivera Viciedo: Conceptualization, Data curation, Formal analysis, Investigation, Methodology, Validation, Visualization, Writing - original draft, Writing - review \& editing. Renato de Mello Prado: Conceptualization, Methodology, Project administration, Resources, Methodology, Supervision, Validation, Writing - review \& editing. Carlos Alberto Martinez: Conceptualization, Data curation, Funding acquisition, Investigation, Methodology, Project administration, Resources, Supervision, Validation, Visualization, Writing - review \& editing. Eduardo Habermann: Data curation, Formal analysis, Investigation, Methodology, Validation, Writing - review \& editing. Marisa de Cássia Piccolo: Data curation, Formal analysis, Writing - review \& editing. Alexander Calero Hurtado: Data curation, Formal analysis, Writing - review \& editing. Rafael Ferreira Barreto: Data curation, Formal analysis, Writing - review \& editing. Kolima Peña Calzada: Data curation, Formal analysis, Writing - review \& editing.

\section{Funding Information}

This research was supported by the Sao Paulo Research Foundation (FAPESP), Thematic Project (Grant, 2008/58075-8), and by the Brazilian National Council for Scientific and Technological Development (CNPq) (Grant 446357/2015-4) to C.A.M. The Coordination for the Improvement of Higher Education Personnel (CAPES) and FAPESP provided graduate studentships to D.O.V. and E.H. (Grant 16/09742-8), respectively. This study was financed in part by CAPES - Finance Code 001.

Competing Interests: The authors declare that they have no known competing financial interests or personal relationships that could have appeared to influence the work reported in this paper.

Competing Interests: The authors declare that they have no known competing financial interests or personal relationships that could have appeared to influence the work reported in this paper. 


\section{References}

Alzate-Marin, A.L., Rivas, P.M.S., Galaschi-Teixeira, J.S., Bonifácio-Anacleto, F., Silva, C.C., Schuster, I., Nazareno, A.G., Giuliatti, S., da Rocha Filho, L.C., Garófalo, C.A., Martinez, C.A., 2021. Warming and elevated $\mathrm{CO}_{2}$ induces changes in the reproductive dynamics of a tropical plant species. Sci. Total Environ. 768, 144899. https://doi.org/10.1016/j.scitotenv.2020.144899

Barreto, R.F., Prado, R. de M., Habermann, E., Viciedo, D.O., Martinez, C.A., 2020. Warming Change Nutritional Status and Improve Stylosanthes capitata Vogel Growth Only Under Well-Watered Conditions. J. Soil Sci. Plant Nutr. https://doi.org/10.1007/s42729-020-00255-5

Bataglia, O., Teixeira, J., Furlani, P., Furlani, A., 1983. Métodos de análise química de plantas. Campina: IAC.

Boddey, R.M., Casagrande, D.R., Homem, B.G.C., Alves, B.J.R., 2020. Forage legumes in grass pastures in tropical Brazil and likely impacts on greenhouse gas emissions: A review. Grass Forage Sci. https://doi.org/10.1111/gfs.12498

Bustamante, M.M.C., Nobre, C.A., Smeraldi, R., Aguiar, A.P.D., Barioni, L.G., Ferreira, L.G., Longo, K., May, P., Pinto, A.S., Ometto, J.P.H.B., 2012. Estimating greenhouse gas emissions from cattle raising in Brazil. Clim. Change 115, 559-577. https://doi.org/10.1007/s10584-012-0443-3

Climate-Data, 2020. Clima Ribeirão Preto: Temperatura, Climograma y Tabla climática para Ribeirão Preto - Climate-Data.org. Clima Ribeirão Preto. URL https://es.climate-data.org/america-delsur/brasil/san-pablo/ribeirao-preto-3193/ (accessed 4.25.21).

Gerdol, R., Marchesini, R., lacumin, P., 2016. Bedrock geology interacts with altitude in affecting leaf growth and foliar nutrient status of mountain vascular plants. J. Plant Ecol. 10, rtw092.

https://doi.org/10.1093/jpe/rtw092

Habermann, E., Contin, D., Olivera-Viciedo, D., Barreto, R., Moraes, M., De Oliveira, E., Martinez, C., 2020. Efeito das Mudanças Climáticas em Plantas Cultivadas e Nativas: Atual Estado das Pesquisas Brasileiras, in: Avanços e Atualidades Na Botânica Brasileira. Brasil, pp. 109-124. https://doi.org/10.35170/ss.ed.9786586283006.08

Habermann, E., Dias de Oliveira, E.A., Contin, D.R., Delvecchio, G., Viciedo, D.O., de Moraes, M.A., de Mello Prado, R., de Pinho Costa, K.A., Braga, M.R., Martinez, C.A., 2019a. Warming and water deficit impact leaf photosynthesis and decrease forage quality and digestibility of a C4 tropical grass. Physiol. Plant. 165, 383-402. https://doi.org/10.1111/ppl.12891

Habermann, E., Dias de Oliveira, E.A., Delvecchio, G., Belisário, R., Barreto, R.F., Viciedo, D.O., Rossingnoli, N.O., de Pinho Costa, K.A., de Mello Prado, R., Gonzalez-Meler, M., Martinez, C.A., 2021. How does leaf physiological acclimation impact forage production and quality of a warmed managed pasture of 
Stylosanthes capitata under different conditions of soil water availability? Sci. Total Environ. 759, 143505. https://doi.org/10.1016/j.scitotenv.2020.143505

Habermann, E., San Martin, J., Contin, D., Bossan, V., Barboza, A., Braga, M., Groppo, M., Martinez, C., 2019b. Increasing atmospheric $\mathrm{CO} 2$ and canopy temperature induces anatomical and physiological changes in leaves of the C4 forage species Panicum maximum. PLoS One 14, e0212506.

https://doi.org/10.1371/journal.pone.0212506

Hatfield, J.L., Prueger, J.H., 2015. Temperature extremes: Effect on plant growth and development. Weather Clim. Extrem. 10, 4-10. https://doi.org/10.1016/j.wace.2015.08.001

Hermans, C., Hammond, J.P., White, P.J., Verbruggen, N., 2006. How do plants respond to nutrient shortage by biomass allocation? Trends Plant Sci. https://doi.org/10.1016/j.tplants.2006.10.007

Herrero, M., Henderson, B., Havlík, P., Thornton, P.K., Conant, R.T., Smith, P., Wirsenius, S., Hristov, A.N., Gerber, P., Gill, M., Butterbach-Bahl, K., Valin, H., Garnett, T., Stehfest, E., 2016. Greenhouse gas mitigation potentials in the livestock sector. Nat. Clim. Chang. https://doi.org/10.1038/nclimate2925

IBGE, 2020. Rebanho bovino tem leve alta em 2019, após dois anos seguidos de quedas | Agência de Notícias | IBGE. URL https://agenciadenoticias.ibge.gov.br/agencia-noticias/2012-agencia-denoticias/noticias/29164-rebanho-bovino-tem-leve-alta-em-2019-apos-dois-anos-seguidos-de-quedas (accessed 2.28.21).

Ikhuoso, O.., Adegbeye, M.J., Elghandour, M.M.Y., Mellado, M., Al-Dobaib, S.N., Salem, A.Z.M., 2020. Climate change and agriculture: The competition for limited resources amidst crop farmers-livestock herding conflict in Nigeria - A review. J. Clean. Prod. 272, 123104.

https://doi.org/10.1016/j.jclepro.2020.123104

Khanzada, H., Wassan, G.M., He, H., Mason, A.S., Keerio, A.A., Khanzada, S., Faheem, M., Solangi, A.M., Zhou, Q., Fu, D., Huang, Y., Rasheed, A., 2020. Differentially evolved drought stress indices determine the genetic variation of Brassica napus at seedling traits by genome-wide association mapping. J. Adv. Res. 24, 447-461. https://doi.org/10.1016/j.jare.2020.05.019

Kong, Q., Guerreiro, S.B., Blenkinsop, S., Li, X.F., Fowler, H.J., 2020. Increases in summertime concurrent drought and heatwave in Eastern China. Weather Clim. Extrem. 28, 100242. https://doi.org/10.1016/j.wace.2019.100242 
Marschner, P., 2011. Marschner's Mineral Nutrition of Higher Plants: Third Edition, Marschner's Mineral Nutrition of Higher Plants: Third Edition. Elsevier Inc. https://doi.org/10.1016/C2009-0-63043-9

Martinez, C., Bianconi, M., Silva, L., Approbato, A., Lemos, M., Santos, L., Curtarelli, L., Rodrigues, A., Mello, T., Manchon, F., 2014. Moderate warming increases PSIl performance, antioxidant scavenging systems and biomass production in Stylosanthes capitata Vogel. Environ. Exp. Bot. 1, 58-67.

O'Mara, F.P., 2012. The role of grasslands in food security and climate change. Ann. Bot. 110, 1263-70. https://doi.org/10.1093/aob/mcs209

Oliveira, T.., de Lucas, R.C., Scarcella, A.S. de A., Contato, A.G., Pasin, T.M., Martinez, C.A., Polizeli, M. de L.T. de M., 2020. Effects of multiple climate change factors on exoenzyme activities and $\mathrm{CO}_{2}$ efflux in a tropical grassland. Soil Biol. Biochem. 148, 107877. https://doi.org/10.1016/j.soilbio.2020.107877

Olivera-Viciedo, D., de Mello Prado, R., Martínez, C.A., Habermann, E., de Cássia Piccolo, M., 2019. Shortterm warming and water stress affect Panicum maximum Jacq. stoichiometric homeostasis and biomass production. Sci. Total Environ. 681, 267-274. https://doi.org/10.1016/j.scitotenv.2019.05.108

Olivera-Viciedo, D., de Mello Prado, R., Martinez, C.A., Habermann, E., de Cássia Piccolo, M., Calero Hurtado, A., Barreto, R.F., Peña Calzada, K., 2021a. Changes in soil water availability and air-temperature impact biomass allocation and C:N:P stoichiometry in different organs of Stylosanthes capitata Vogel. J. Environ. Manage. 278. https://doi.org/10.1016/j.jenvman.2020.111540

Olivera-Viciedo, D., Mello Prado, R., Lizcano Toledo, R., Salas Aguilar, D., Claudio Nascimento dos Santos, L., Calero Hurtado, A., Peña Calzada, K., Betancourt Aguilar, C., 2020. Physiological role of silicon in radish seedlings under ammonium toxicity. J. Sci. Food Agric. jsfa.10587. https://doi.org/10.1002/jsfa.10587

Olivera-Viciedo, D., Mello Prado, R., Martinez, C.A., Habermann, E., Branco, R.B.F., Cássia Piccolo, M., Calero Hurtado, A., Peña Calzada, K., Lata Tenesaca, L.F., 2021b. Water stress and warming impact nutrient use efficiency of Mombasa grass (Megathyrsus maximus) in tropical conditions. J. Agron. Crop Sci. 207, 128-138. https://doi.org/10.1111/jac.12452

Onoda, Y., Wright, I.J., Evans, J.R., Hikosaka, K., Kitajima, K., Niinemets, Ü., Poorter, H., Tosens, T., Westoby, M., 2017. Physiological and structural tradeoffs underlying the leaf economics spectrum. New Phytol. 214, 1447-1463. https://doi.org/10.1111/nph.14496

Ortiz-Bobea, A., Ault, T.R., Carrillo, C.M., Chambers, R.G., Lobell, D.B., 2021. Anthropogenic climate change has slowed global agricultural productivity growth. Nat. Clim. Chang. 11, 306-312. https://doi.org/10.1038/s41558-021-01000-1 
Santos, M.O., Sassaki, R.P., Chiari, L., Resende, R.M.S., de Souza, A.P., 2009. Isolation and characterization of microsatellite loci in tropical forage Stylosanthes capitata Vogel. Mol. Ecol. Resour. 9, 192-194. https://doi.org/10.1111/j.1755-0998.2008.02308.x

Shaw, N.H., 1961. Increased beef production from Townsville lucerne (Stylosanthes sundaica Taub.) in the spear grass pastures of central coastal Queensland. Aust. J. Exp. Agric. 1, 73-80.

https://doi.org/10.1071/EA9610073

Sherwood, S.C., Webb, M.J., Annan, J.D., Armour, K.C., Forster, P.M., Hargreaves, J.C., Hegerl, G., Klein, S.A., Marvel, K.D., Rohling, E.J., Watanabe, M., Andrews, T., Braconnot, P., Bretherton, C.S., Foster, G.L., Hausfather, Z., von der Heydt, A.S., Knutti, R., Mauritsen, T., Norris, J.R., Proistosescu, C., Rugenstein, M., Schmidt, G.A., Tokarska, K.B., Zelinka, M.D., 2020. An Assessment of Earth's Climate Sensitivity Using Multiple Lines of Evidence. Rev. Geophys. https://doi.org/10.1029/2019RG000678

Tietjen, B., Schlaepfer, D.R., Bradford, J.B., Lauenroth, W.K., Hall, S.A., Duniway, M.C., Hochstrasser, T., Jia, G., Munson, S.M., Pyke, D.A., Wilson, S.D., 2017. Climate change-induced vegetation shifts lead to more ecological droughts despite projected rainfall increases in many global temperate drylands. Glob. Chang. Biol. 23, 2743-2754. https://doi.org/10.1111/gcb.13598

Veloso, G.A., Ferreira, M.E., Ferreira Júnior, L.G., Barbosa da Silva, B., 2020. Modelling gross primary productivity in tropical savanna pasturelands for livestock intensification in Brazil. Remote Sens. Appl. Soc. Environ. 17, 100288. https://doi.org/10.1016/j.rsase.2020.100288

Ventura, R., Ferraudo, A.S., Martínez, C.A., Gratão, P.L., 2020. Global warming: Antioxidant responses to deal with drought and elevated temperature in Stylosanthes capitata, a forage legume. J. Agron. Crop Sci. 206, 13-27. https://doi.org/10.1111/jac.12367

Wang, J., Mao, Y., Huang, T., Lu, W., Lu, D., 2020. Water and heat stresses during grain formation affect the physicochemical properties of waxy maize starch. J. Sci. Food Agric. jsfa.10743.

https://doi.org/10.1002/jsfa.10743

\section{Figures}




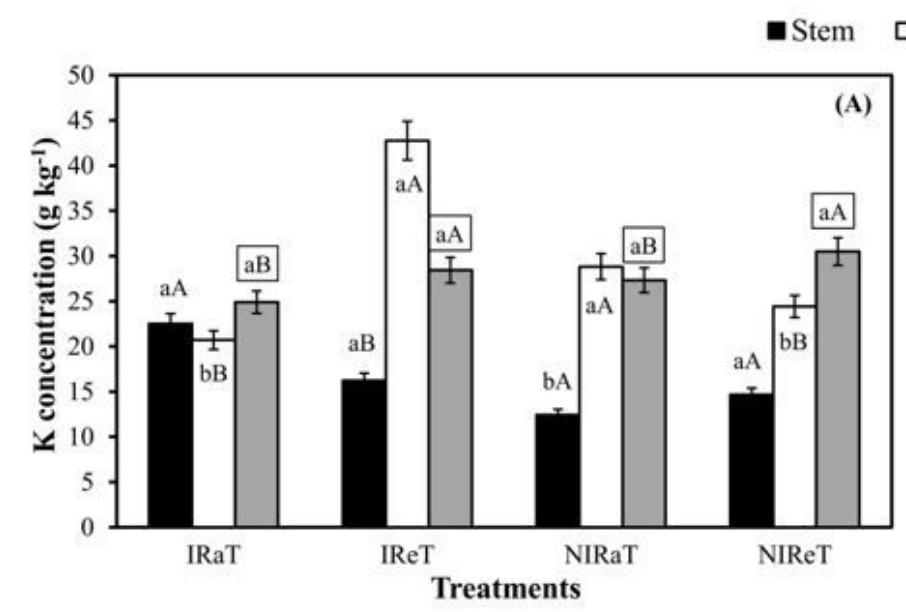

$\square$ Leaf $\square$ Inflorescence
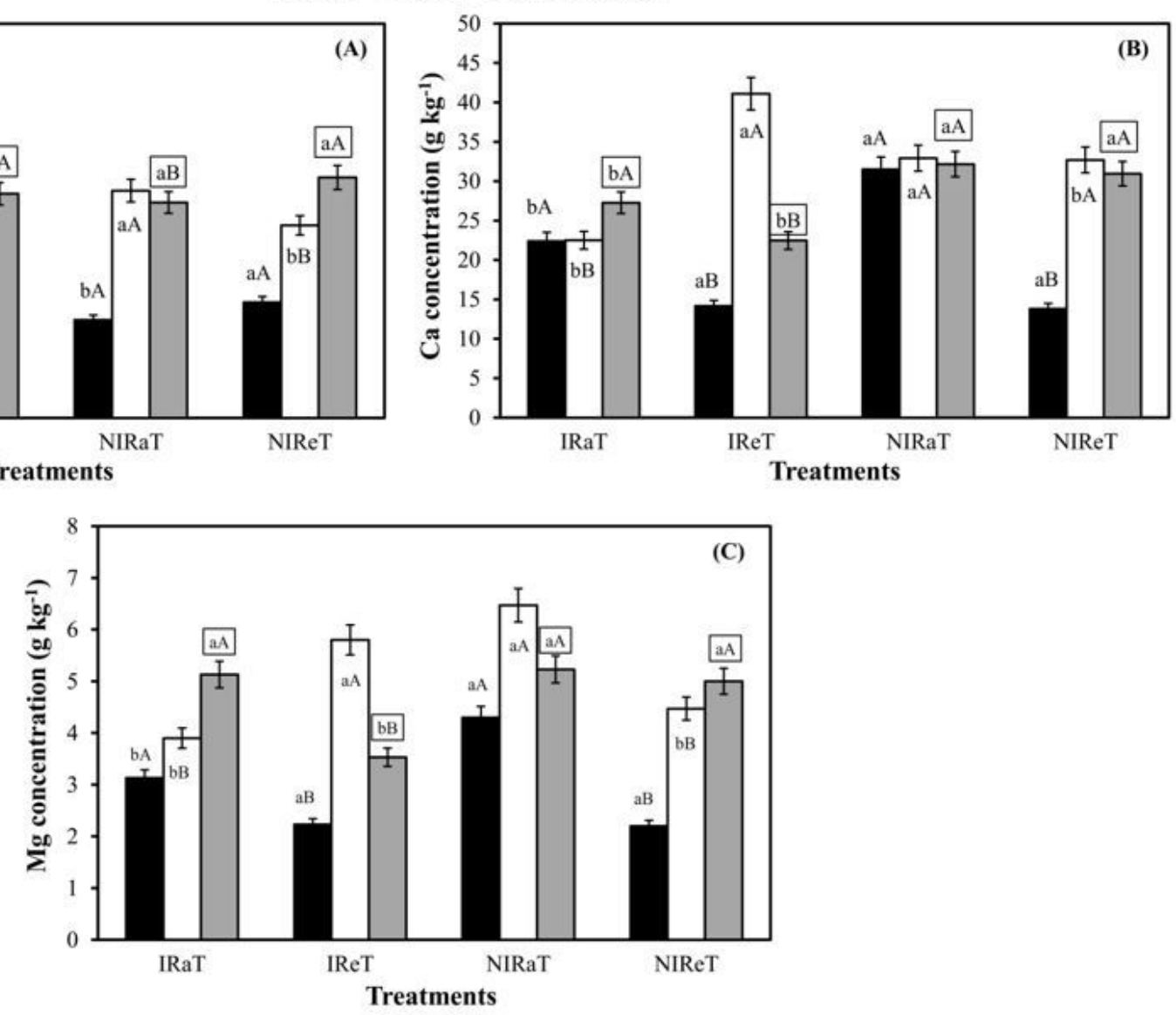

\section{Figure 1}

Nutrient concentration in different aerial organs of Stylosanthes capitata. $\mathrm{K}(\mathrm{A}), \mathrm{Ca}(\mathrm{B})$, and $\mathrm{Mg}(\mathrm{C})$ in response to treatments. Irrigated and ambient temperature (IRaT), irrigated and $+2^{\circ} \mathrm{C}$ above ambient temperature (IReT), non-irrigated and ambient temperature (NIRaT), non-irrigated and $+2^{\circ} \mathrm{C}$ above ambient temperature (NIReT). Vertical bars represent the mean \pm standard error $(n=3)$. Different lowercase letter $(a, b)$ indicates significant differences between different soil water regime at the same temperature, and different $(A, B)$ uppercase letters indicate significant differences within the same soil water regime at the different temperatures, according to the $F$ test $(P \leq 0.05)$. 

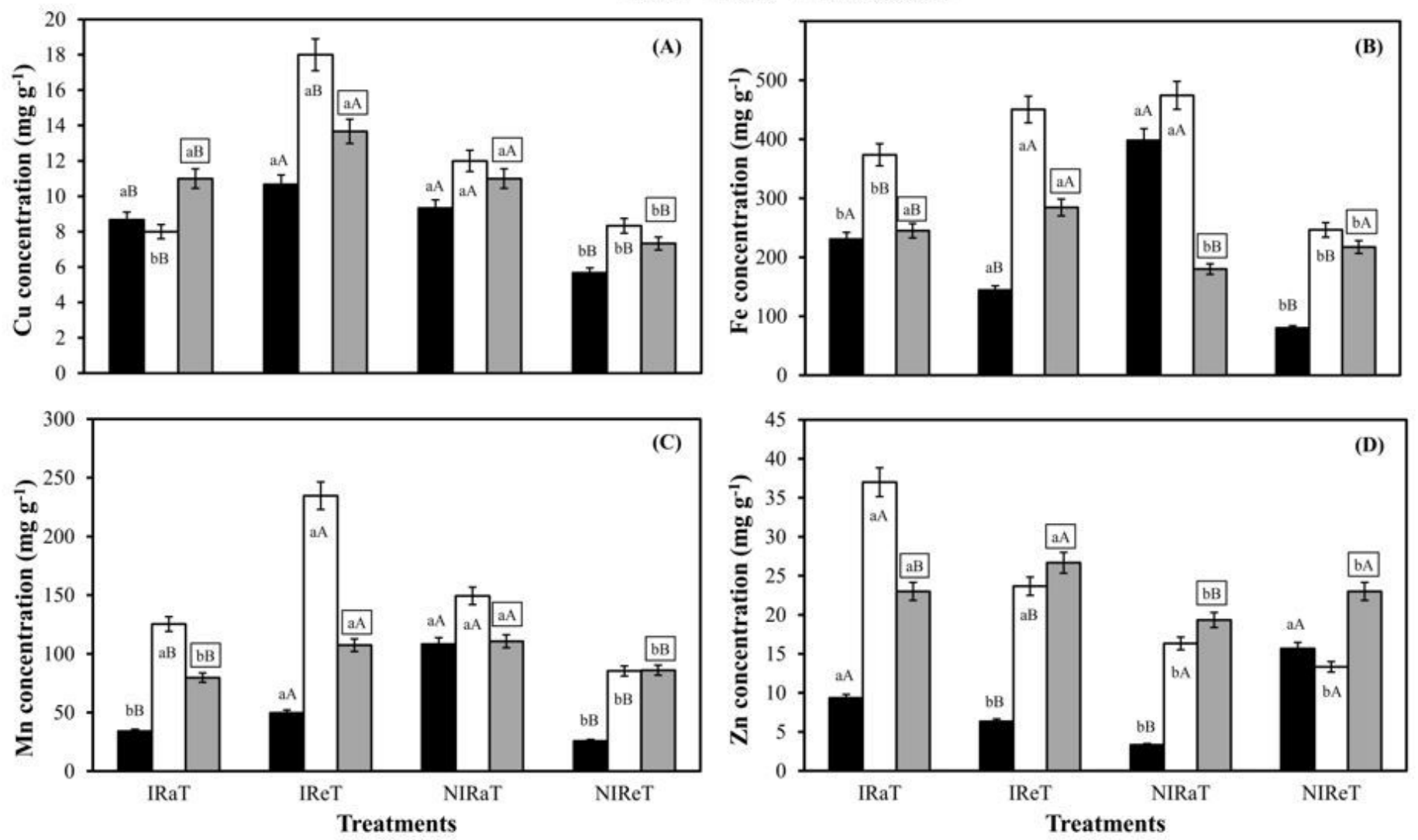

Figure 2

Nutrient concentration in different aerial organs of Stylosanthes capitata. $\mathrm{Cu}(\mathrm{A}), \mathrm{Fe}(\mathrm{B}), \mathrm{Mn}$ (C) and Zn (D) in response to treatments. Irrigated and ambient temperature (IRaT), irrigated and $+2^{\circ} \mathrm{C}$ above ambient temperature (IReT), non-irrigated and ambient temperature (NIRaT), non-irrigated and $+2{ }^{\circ} \mathrm{C}$ above ambient temperature (NIReT). Vertical bars represent the mean \pm standard error $(n=3)$. Different lowercase letter $(a, b)$ indicates significant differences between different soil water regime at the same temperature, and different $(A, B)$ uppercase letters indicate significant differences within the same soil water regime at the different temperatures, according to the $F$ test $(P \leq 0.05)$. 

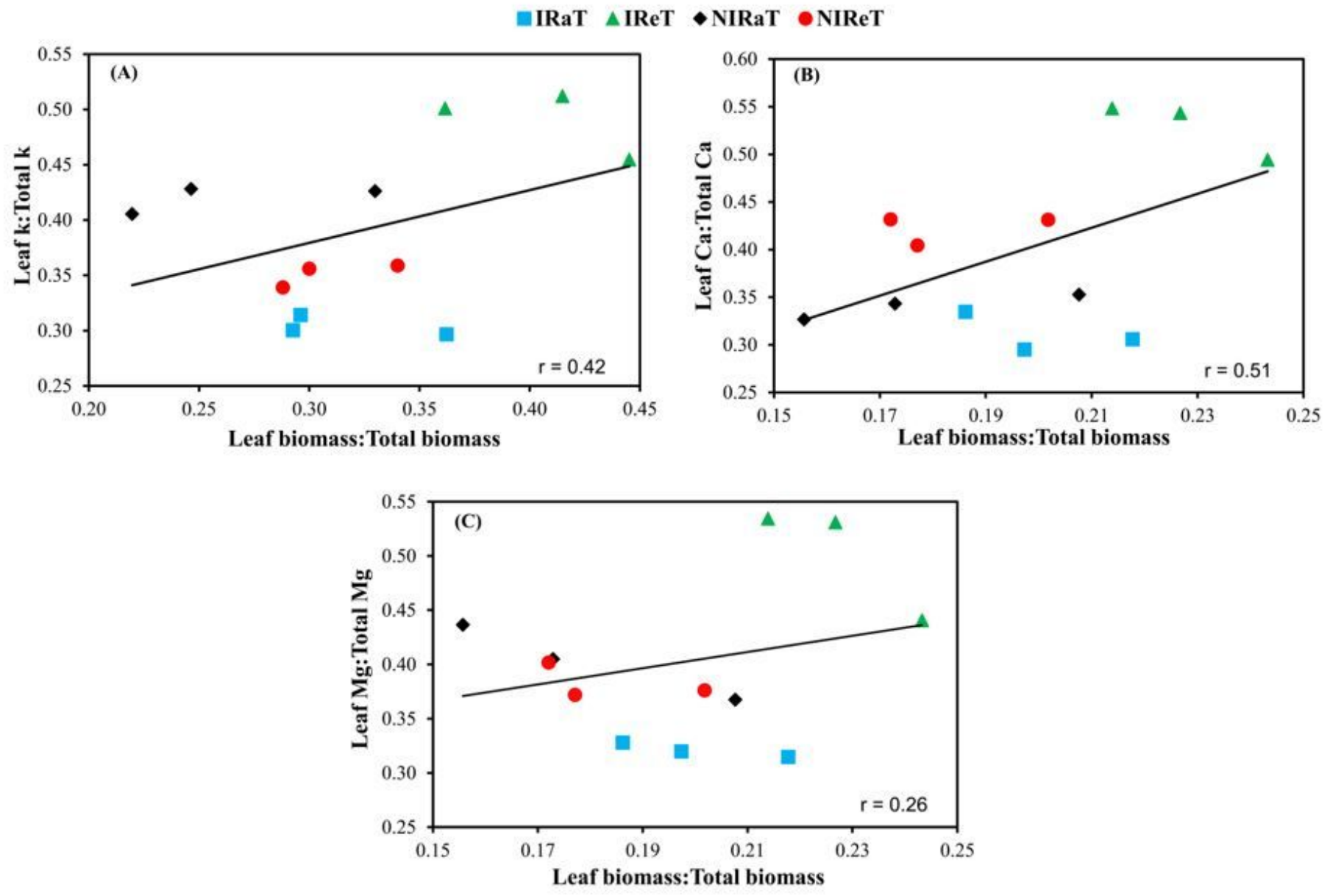

Figure 3

Correlation analysis between leaf nutrient concentrations and biomass ratios of Stylosanthes capitata. $\mathrm{K}$ (A), $\mathrm{Ca}(\mathrm{B})$, and $\mathrm{Mg}(\mathrm{C})$ in response to treatments. Irrigated and ambient temperature (IRaT), irrigated and $+2^{\circ} \mathrm{C}$ above ambient temperature (IReT), non-irrigated and ambient temperature (NIRaT), non-irrigated and $+2^{\circ} \mathrm{C}$ above ambient temperature (NIReT). $r=$ correlation coefficient. 
EIRaT $\triangle$ IReT $\bullet$ NIRaT $\bullet$ NIReT
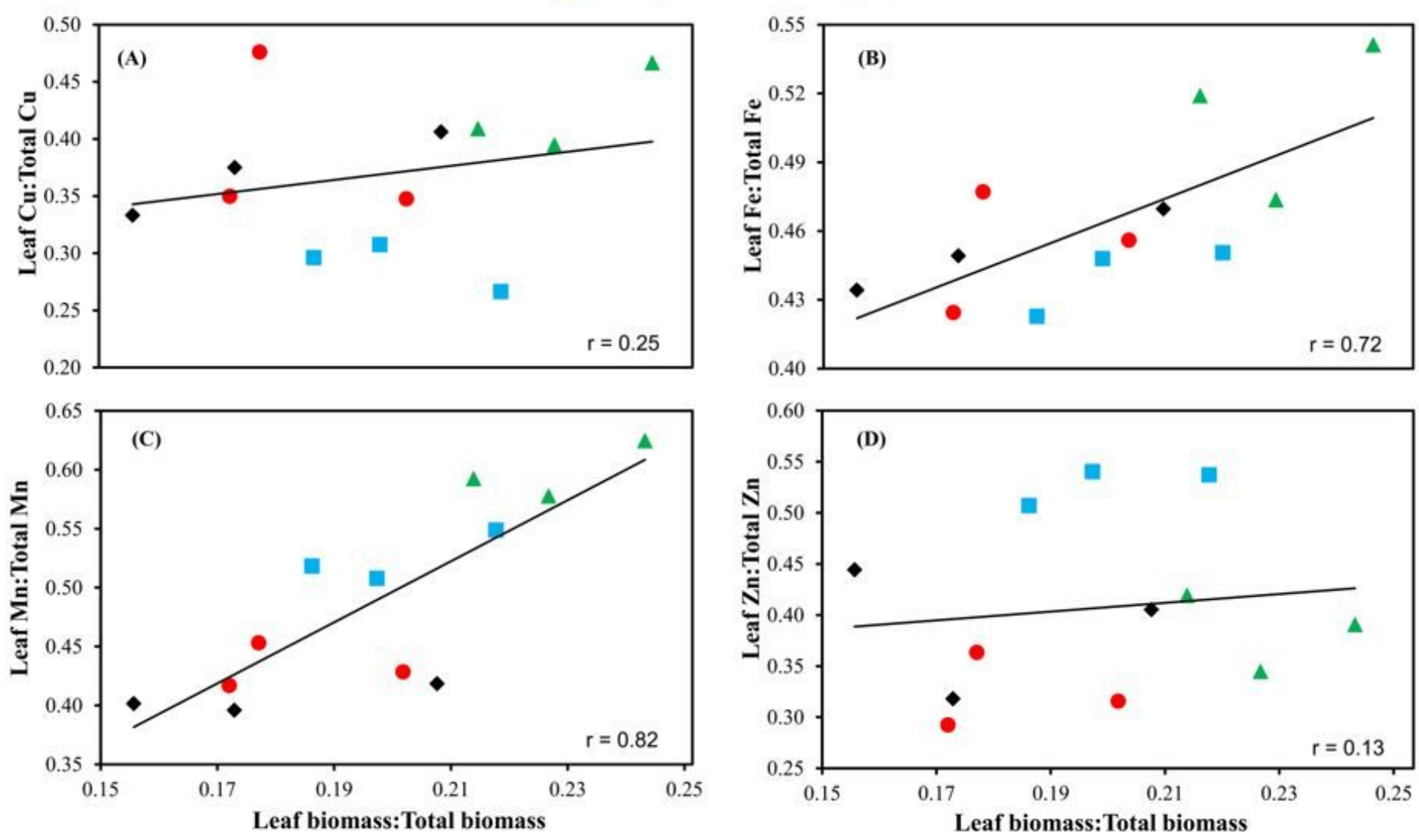

Figure 4

Correlation analysis between leaf nutrient concentrations and biomass ratios of Stylosanthes capitata. $\mathrm{Cu}(\mathrm{A}), \mathrm{Fe}(\mathrm{B}), \mathrm{Mn}(\mathrm{C})$, and $\mathrm{Zn}(\mathrm{D})$ in response to treatments. Irrigated and ambient temperature (IRaT), irrigated and $+2^{\circ} \mathrm{C}$ above ambient temperature (IReT), non-irrigated and ambient temperature (NIRaT), non-irrigated and $+2{ }^{\circ} \mathrm{C}$ above ambient temperature (NIReT). $r=$ correlation coefficient. 


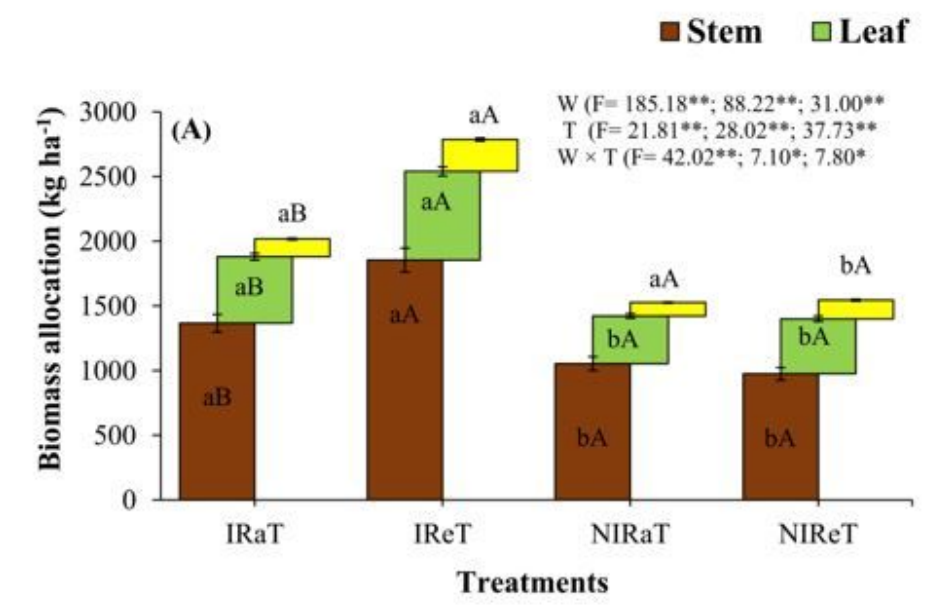

$\square$ Inflorescence
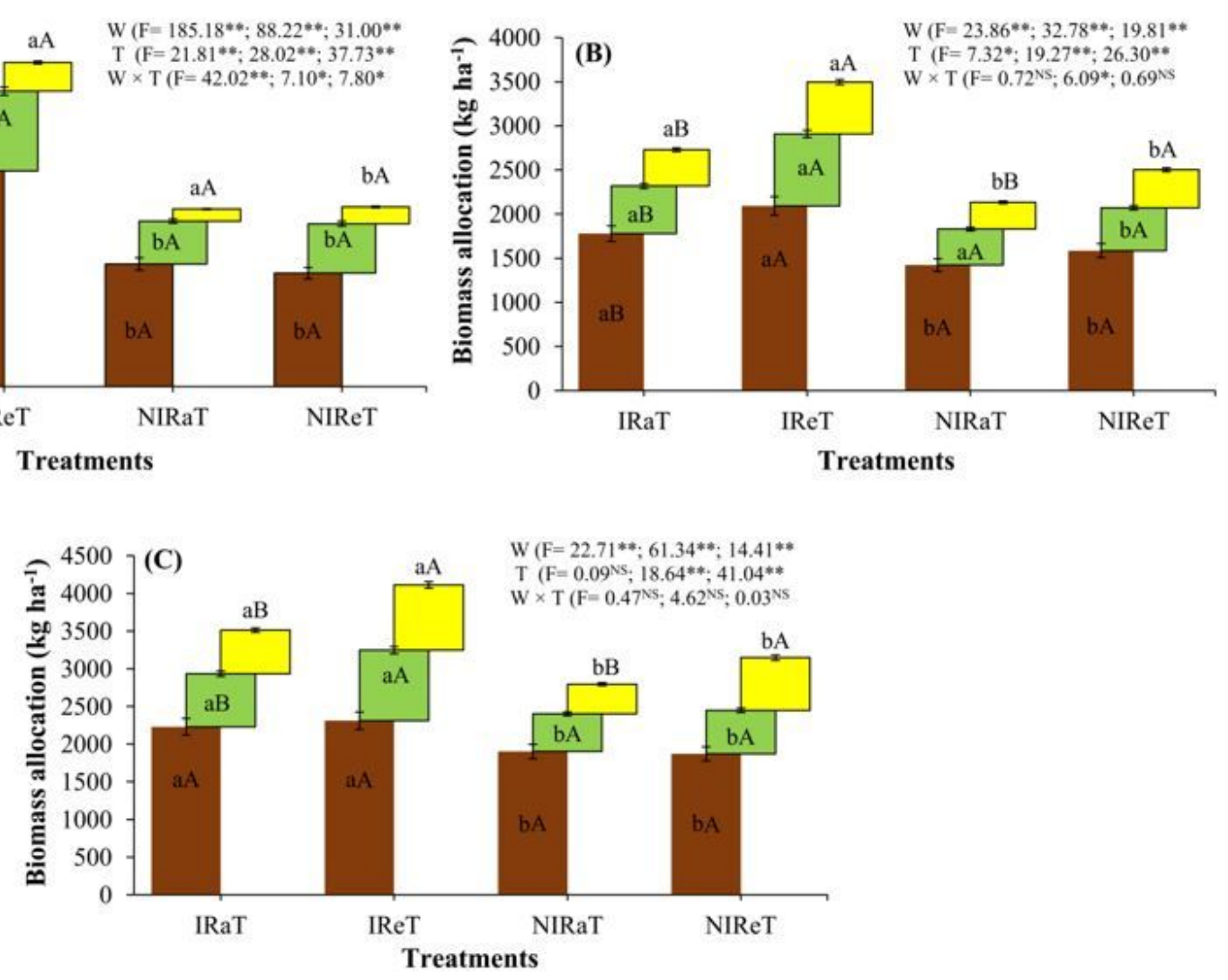

\section{Figure 5}

Biomass production of different aerial organs of Stylosanthes capitata during the first $(A)$, second $(B)$, and third (C) sampling date of plants exposed to rainfed and warming conditions, both as individual or combined factors. Irrigated and ambient temperature (IRaT), irrigated and $+2^{\circ} \mathrm{C}$ above ambient temperature (IReT), non-irrigated and ambient temperature (NIRaT), non-irrigated and $+2{ }^{\circ} \mathrm{C}$ above ambient temperature (NIReT). Different lowercase letter $(a, b)$ indicates significant differences between different soil water regime at the same temperature, and different $(A, B)$ uppercase letters indicate significant differences within the same soil water regime at the different temperatures, according to the $F$ test. Vertical bars represent means and standard error of three replicates. ${ }^{*} p \leq 0.05$; ${ }^{*} p \leq 0.01$; NS, not significant; $\mathrm{W}$ : water availability; $\mathrm{T}$ : temperature; $\mathrm{W} \times \mathrm{T}$ interaction; and $\mathrm{F}$ values from ANOVA (stem, leaf, and inflorescences).

\section{Supplementary Files}

This is a list of supplementary files associated with this preprint. Click to download.

- Supplementarymaterial.docx 